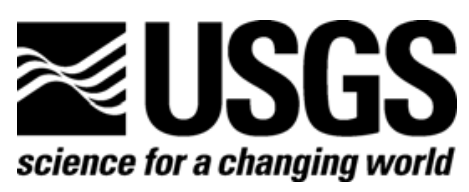

\title{
PUBLICATIONS OF THE WESTERN EARTH SURFACE PROCESSES TEAM 2005
}

Compiled by Charles Powell, II, and Paul Stone

Report Series 2007-1027

U.S. Department of the Interior

U.S. Geological Survey 


\title{
U.S. Department of the Interior \\ Lynn Scarlett, Acting Secretary
}

\section{U.S. Geological Survey \\ P. Patrick Leahy, Acting Director}

\author{
U.S. Geological Survey, Menlo Park, California 2006 \\ Revised and reprinted:
}

For product and ordering information:

World Wide Web: http://www.usgs.gov/pubprod

Telephone: 1-888-ASK-USGS

For more information on the USGS - the Federal source for science about the Earth, its natural and living resources, natural hazards, and the environment:

World Wide Web: http://www.usgs.gov

Telephone: 1-888-ASK-USGS

Suggested citation:

Powell, C.L., II, and Stone, Paul, 2007, PUBLICATIONS OF THE WESTERN EARTH SURFACE

PROCESSES TEAM 2005: U.S. Geological Survey Open-File Report 2007-1027, I-iv + 22 p.

Any use of trade, product, or firm names is for descriptive purposes only and does not imply endorsement by the U.S. Government.

Although this report is in the public domain, permission must be secured from the individual copyright owners to reproduce any copyrighted material contained within this report. 


\section{Contents}

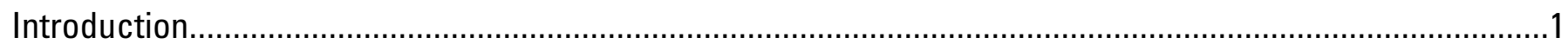

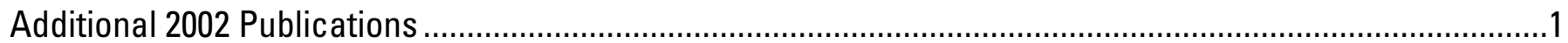

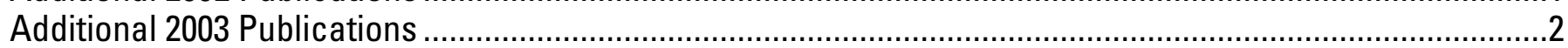

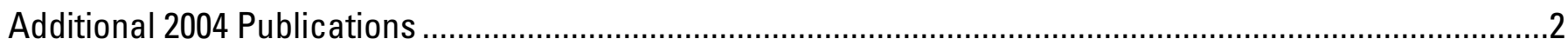

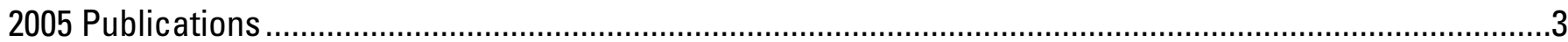




\title{
PUBLICATIONS OF THE WESTERN EARTH SURFACE PROCESSES TEAM 2005
}

\author{
Compiled by Charles Powell, II, and Paul Stone ${ }^{1}$
}

\section{INTRODUCTION}

The Western Earth Surface Processes Team (WESPT) of the U.S. Geological Survey (USGS) conducts geologic mapping, earth-surface process investigations, and related topical earth science studies in the western United States. This work is focused on areas where modern geologic maps and associated earth-science data are needed to address key societal and environmental issues such as ground-water quality, landslides and other potential geologic hazards, and land-use decisions. Areas of primary emphasis in 2005 included southern California, the San Francisco Bay region, the Mojave Desert, the Colorado Plateau region of northern Arizona, and the Pacific Northwest. The team has its headquarters in Menlo Park, California, and maintains smaller field offices at several other locations in the western United States.

The results of research conducted by the WESPT are released to the public as a variety of databases, maps, text reports, and abstracts, both through the internal publication system of the USGS and in diverse external publications such as scientific journals and books. This report lists publications of the WESPT released in 2005 as well as additional 2002 , 2003, and 2004 publications that were not included in the previous lists (USGS Open-File Reports 03-363, 20041267, 2005-1362). Most of the publications listed were authored or coauthored by WESPT staff. The list also includes some publications authored by non-USGS cooperators with the WESPT, as well as some authored by USGS staff outside the WESPT in cooperation with WESPT projects.

Several of the publications listed are available on the World Wide Web; for these, URL addresses are provided. Many of these web publications are USGS Open-File reports that contain large digital databases of geologic map and related information.

Information on ordering USGS publications can be found on the World Wide Web at http://www.usgs.gov/pubprod/, or by calling 1-888-ASK-USGS. The U.S. Geological Survey's web server for geologic information in the western United States is located at http://geology.wr.usgs.gov/. More information is available about the WESPT is available on-line at http://geology.wr.usgs.gov/wgmt.

\section{Additional 2002 Publication}

Hiza, M.M., 2002, Factors affecting sand dune mobility on the Navajo Nation, AZ USA [abs.], in Lee, J.A. and Zobeck, T.M., 2002, Proceedings of ICAR5/GCTE-SEN Joint Conference, International Center for Arid and Semiarid Lands Studies (Texas Tech University, Lubbock, TX), USA Publication, 02-2 p. 385.

\footnotetext{
${ }^{1}$ Earth Surface Processes Team, U.S. Geological Survey, 345 Middlefield Road, Menlo Park, CA 94025
} 


\section{Additional 2003 Publications}

Blakely, R.J., Brocher, T.M., and Wells, R.E., 2003, Subduction-zone magnetic anomalies and implications for hydrated forearc mantle: Geology, v. 33, no. 6, p. 445-448.

McPhee, D.K., 2003, Geophysical setting of the San Andreas Fault Observatory at Depth (SAFOD) at Parkfield, California: UNAVCO/IRIS Joint Workshop (Yosemite, Calif., June 18-22, 2003), http://achaia.unavco.org/public/meetings/viewabstract. asp? id=3220\&yr=2003.

\section{Additional 2004 Publications}

Amoroso, L., Pearthree, P.A., and Arrowsmith, J.R., 2004, Paleoseismology and neotectonics of the Shivwits section of the Hurricane fault, northwestern Arizona: Bulletin of the Seismological Society of America, v. 94, no. 5, p. 1919-1942.

Coe, R.S., and Glen, J.M.G., 2004, The complexity of reversals, in Channell, J.E.T., Lowrie, W., and Meert J., eds., Timescales of the internal geomagnetic field: American Geophysical Union, Geophysical Monograph 145, p. 221-232.

Glen, J.M.G., Ponce, D.A., and Sepulveda, E., 2004, Yellowstone hotspot melting and its relation to pre-existing crustal structures and Great Basin extension [abs]: Eos, Transactions, American Geophysical Union, v. 85, no. 47 (supplement), p. F1920.

Jarboe, N., Coe, R.S., Glen, J.M.G., and Renne, P.R., 2004, Investigating the timing and extent of early Yellowstone hotspot volcanism while expanding the Steens Mountain magnetic reversal record [abs.]: Eos, Transactions, American Geophysical Union, v. 85, no. 47 (supplement), p. F639.

Jayko, A. S., 2004, Book Review of 'Morphotectonics' by Adrian E. Scheiddeger: Eos, Transactions, American Geophysical Union, v. 85, no. 44, p. F456.

Peters, K.E., Bird, K.J., Magoon, L.B., Lampe, C., Lillis, P.G., and Verma, M.K., 2004, Modeling petroleum systems on the North Slope of Alaska [abs.]: American Association of Petroleum Geologists Bulletin, v. 88, no. 13 (supplement), p. A110, http://www.searchanddiscovery.com/documents/abstracts/annual2004/Dallas/Peters.htm.

Peters K.E., and Creaney, S., 2004, Geochemical differentiation of Silurian from Devonian crude oils in eastern Algeria, in Geochemical Investigations in Earth and Space Science: A Tribute to Isaac R. Kaplan: The Geochemical Society Special Publication Series 9, p. 287-301.

Phelps, G.A., 2004, Classification of Image Textures Using GRID and a Neural Network:

Proceedings, ESRI International Users Conference (August 9-13, 2004; San Diego, Calif.), http://gis.esri.com/library/userconf/proc04/abstracts/a1434.html.

Stoffer, P., 2004, Photographers of the Powell Survey, 1871-1872: People, Land, \& Water (US DOI), p. 29, May.

Stoffer, P., 2004, 3D Photography of the Powell Survey (1870-1879) of the Colorado River Canyon Country: http://3dparks.wr.usgs.gov/3Dcanyons/index.html.

Stoffer, P., 2004, Geology of Olympic National Park: http://3dparks.wr.usgs.gov/olympic/index.html.

Wells, R.E., 2004, Paleomagnetic rotations in the northwest U.S.-Setting the stage for contemporary deformation models of the Cascadia convergent margin [abs.]: Eos, Transactions, American Geophysical Union, v. 85, no. 47 (supplement), p. F14. 


\section{Publications}

Alvarez, R.M., Morton, D.M., Campbell, R.H., and Bovard, K.R., 2005, 2004-2005 El Niño debris flows in southern California: Some comparisons with previous winters [abs.]: Geological Society of America Abstracts with Programs, v. 37, no. 7, p. 175.

Amoroso, L., and Mahan, S., 2005, Climate linkage with hillslope processes, Hurricane Escarpment, northwestern Arizona [abs.]: Geological Society of America Abstracts with Programs, v. 37, no. 7, p. 480.

Attanasi, E.D., Bird, K.J., and Freeman, P.A., 2005, Economic analysis of undiscovered oil and gas of the central North Slope of Alaska, 2005: U.S. Geological Survey Fact Sheet 2005-3120, 2 p., http://pubs.usgs.gov/fs/2005/3120/.

Bacon, S., Burke, B., Pezzopane, S., and Jayko, A., 2005, Geologic and geomorphic record of late Pleistocene and Holocene lake levels of Owens Lake, eastern California [abs.], in Reheis, M.C., ed., Geologic and biotic perspectives on the late Cenozoic drainage history of the southwestern Great Basin and lower Colorado River region: Conference abstracts: U.S. Geological Survey Open-File Report 2005-1404, p. 15-16, http://pubs.usgs.gov/of/2005/1404/.

Bacon, S.N., Jayko, A.S., and McGeehin, J.P., 2005, Holocene and latest Pleistocene oblique dextral faulting on the southern Inyo Mountains fault, Owens Lake Basin, California: Bulletin of the Seismological Society of America, v. 95, no. 6, p. 2472-2485.

Barnett, E.A., Weaver, C.S., Meagher, K.L., Wang, Z., Madin, I.P., Wang, M., Haugerud, R.A., Wells, R.E., Blakely, R.J., Ballantyne, D.B., Darienzo, M., and the Portland area working group, 2005, Lifelines and earthquake hazards along the Interstate 5 Urban Corridor: Woodburn, Oregon to Centralia, Washington: U.S. Geological Survey Open-File Report 2005-1085, 2 sheets, http://pubs.usgs.gov/of/2005/1085/.

Beard, L.S., Felger, T.J., House, P.K., and Howard, K.A., 2005, Transition from basins to throughflowing drainage of the Colorado River, lower Lake Mead region, Nevada and Arizona [abs.], in Reheis, M.C., ed., Geologic and biotic perspectives on late Cenozoic drainage history of the southwestern Great Basin and lower Colorado River region: Conference abstracts: U.S. Geological Survey Open-File Report 2005-1404, p. 17, http://pubs.usgs.gov/of/2005/1404/.

Beard, L.S., and Martin, K.L., and Duebendorfer, E., 2005, Evaluating tectonic reconstructions for the Lake Mead region, Nevada-California: Insight from stratigraphic studies [abs.]: Geological Society of America Abstracts with Programs, v. 37, no. 7, p. 224.

Bird, K.J., 2005, Assessment of undiscovered oil and gas resources, central North Slope, Alaska [abs.]: 2005 Annual Convention Abstracts Volume, American Association of Petroleum Geologists (Calgary, Alberta, Canada; June 19-22, 2005), p. A16-A17.

Bijoor, S., Glen, J., McPhee, D., and Klemperer, S., 2005, Ultra-low frequency electromagnetic monitoring of earthquakes in the San Francisco Bay area: initial results of an Earthscope PBO Project [abs.]: Eos, Transactions, American Geophysical Union, v. 86, no. 52 (supplement), p. F1837.

Bird, K.J., and Houseknecht, D.W., 2005, Oil and gas assessment of central North Slope, Alaska, 2005: U.S. Geological Survey Fact Sheet 2005-3043, 2 p., http://pubs.usgs.gov/fs/2005/3043/.

Blakely, R.J., Hillhouse, J.W., and Morin, R.L., 2005, Ground-magnetic studies of the Amargosa Desert region, California and Nevada: U.S. Geological Survey Open-File Report 2005-1132, 23 p., http://pubs.usgs.gov/of/2005/1132/.

Blakely, R.J., Hughes, J.F., Sherrod, B.L., and Wells, R.E., 2005, Hunting the Saddle Mountain fault zone in the Olympic Peninsula with airplane and canoe [abs.]: Eos, Transactions, American Geophysical Union, v. 86, no. 52 (supplement), p. F1438. 
Blakely, R.J., Sherrod, B.L., Wells, R.E., Weaver, C.S., Brocher, T.M., and Kelsey, H.M., 2005, Finding active faults in a glaciated and urban landscape: the southern Whidbey Island fault, Washington [abs.]: Geological Society of America Abstracts with Programs, v. 37, no. 7, p. 449450.

Booth, D.B., and Troost, K.G., 2005, Geologic map of the Olalla 7.5-minute quadrangle, King, Kitsap, and Pierce Counties, Washington: U.S. Geological Survey Scientific Investigations Map 2902, scale 1:24,000, http://pubs.usgs.gov/sim/2005/2902/.

Booth, D.B., Troost, K.G., and Shimel, S.A., 2005, Geologic map of northwestern Seattle (part of the Seattle North 7.5' x 15' Quadrangle), King County, Washington: U.S. Geological Survey Scientific Investigations Map 2903, scale 1:12,000, http://pubs.usgs.gov/sim/2005/2903/.

Brabb, E.E., and Parker, J.M., 2005, Location and age of foraminifer samples collected by Chevron Petroleum geologists in California, revised: U.S. Geological Survey Open-File Report 03-167, version 2, 13 p. + 1,741 data sheets, http://pubs.usgs.gov/of/2003/of03-167/.

Brabb, E.E., Ristau, D., Bukry, D., McDougall, K., Saul, L., Sanfilippo, A., Almgren, A.A., Jones, D.L., and Barron, J.A., 2005, Not the Rosetta Stone [abs.]: Geological Society of America Abstracts with Programs, v. 37, no. 4, p. 41.

Campbell, R.H., Alvarez, R.M., Morton, D.M., and Bovard, K.R., 2005, Spatial distribution of rainfall characteristics associated with debris flows in the 2004-2005 season in southern California [abs.]: Geological Society of America Abstracts with Programs, v. 37, no. 7, p. 175.

Castle, R.O., Gilmore, T.D., Walker, J.P., and Castle, S.A., 2005, Height changes along selected lines through the Death Valley region, California and Nevada, 1905-1984: U.S. Geological Survey Open-File Report 2005-1133, 35 p., http://pubs.usgs.gov/of/2005/1133/.

Chamberlain, J.A., Jr., Palamarczuk, S., Terry, D.O., Jr., Stoffer, P.W., Becker, M.A., Garb, M.P., and Jannet, P., 2005, Biostratigraphy and age of the lower Fairpoint Member of the Fox Hills Formation (Maastrichtian), badlands area of South Dakota [abs.]: Geological Society of America Abstracts with Programs, v. 37, no. 7, p. 370.

Clynne, M.A., Wolff, E.W., Calvert, A.T., Pallister, J.S., Champion, D.E., Lanphere, M.A., and Evarts, R.C., 2005, Eruptive history of Mount St. Helens, Washington-A summary with new data [abs.]: Geochimica et Cosmochimica Acta, v. 69, no. 10, supplement 1, p. A270.

Coleman, R.G., Jachens, R.C., and Wentworth, C.M., 2005, Serpentinites in the San Jose area, California [abs.]: Geological Society of America Abstracts with Programs, v. 37, no. 4, p. 91. Cook, H.E., 2005, Carbonate sequence stratigraphy: An exploration tool for sediment-hosted, disseminated gold deposits in the Great Basin, in Rhoden, H.N., Steininger, R.C., and Vikre P.G., eds., Geological Society of Nevada Symposium 2005: Window to the World (Reno, NV), p. 1924.

Conrey, R.M., Evarts, R.C., and Fleck, R.J., 2005, Location of the Miocene - Pleistocene Cascade volcanic front in the Portland Basin [abs.]: Geochimica et Cosmochimica Acta, v. 69, no. 10, supplement 1, p. A267.

Cox, B.F., 2005, New geologic map of the Newberry Mountains, southern California, and implications for Miocene tectonic history of the Mojave Desert [abs.]: Geological Society of America Abstracts with Programs, v. 37, no. 7, p. 441-442.

Crews, J.M., Stanley, R.G., Till, A.B., Lillis, P.G., and Simpson, M.K., 2005, Surface thermal maturity of the Yukon Flat region, east-central Alaksa [abs.]: Geological Society of America Abstracts with Programs, v. 37, no. 4, p. 95.

David, B.T., Liddicoat, J.C., Sarna-Wojcicki, A.M., Knott, J.R., and Machette, M.N., 2005, Geochronology and stratigraphy of the upper Furnace Creek Formation, Death Valley, Inyo 
County, California [abs.]: Geological Society of America Abstracts with Programs, v. 37, no. 4, p. 46.

Deino, A.L., Glen, J.M., Kingston, J., and Hill, A., 2005, Precessional climatic signal in the Plio-

Pleistocene Chemeron Formation, central Kenya Rift [abs.]: Geochimica et Cosmochimica Acta, v. 69, no. 10, supplement 1, p. A323.

Dethier, D.P., Sarna-Wojcicki, A.M., and Fleck, R.J., 2005, Interglacial pumice in Whidbey Formation at Blowers Bluff, central Whidbey Island, Washington [abs.]: Geological Society of America Abstracts with Programs, v. 37, no. 7, p. 180.

Dewitt, E.H., Langenheim, V.E., and Wirt, L., 2005, Miocene and Pliocene extensional basins of north-central Arizona [abs.]: Geological Society of America Abstracts with Programs, v. 37, no. 7, p. 496.

Dorsey, R.J., Fluette, A., McDougall, K., Housen, B.A., and Janecke, S.U., 2005, Terminal Miocene arrival of Colorado River sand in the Salton Trough, southern California: implications for initiation of the lower Colorado River drainage [abs.]: Geological Society of America Abstracts with Programs, v. 37, no. 7, p. 109.

Dudash, S.L., and Miller, D.M., 2005, New data from the Coyote Lake arm of Lake Manix, California: Post-Manix lake history [abs.]: Geological Society of America Abstracts with Programs, v. 37, no. 7, p. 64.

Ebbs, V.M., Liddicoat, J.C., Sarna-Wojcicki, A.M., and Knott, J.R., 2005, Tephrochronology of the northern Kit Fox Hills, Death Valley, California [abs.]: Geological Society of America Abstracts with Programs, v. 37, no. 4, p. 47.

Evarts, R.C., 2005, Geologic map of the Amboy quadrangle, Clark and Cowlitz Counties, Washington: U.S. Geological Survey Scientific Investigations Map 2885, 26 p., scale 1:24,000, http://pubs.usgs.gov/sim/2005/2885/.

Evarts, R.C., 2005, Cascade volcanic arc of southwestern Washington: the early years [abs.]: Geochimica et Cosmochimica Acta, v. 69, no. 10, supplement 1, p. A274.

Fisher, M.A., Langenheim, V.E., Sorlien, C.C., Dartnell, P., Sliter, R.W., Cochrane, G.R., and Wong, F.L., 2005, Recent deformation along the offshore Malibu Coast, Dume, and related faults west of Point Dume, southern California: Bulletin of the Seismological Society of America, v. 95, no. 6, p. 2486-2500.

Fisher, M.A., Ratchkovski, N., Wells, R.E., Eberhart-Phillips, D.M., Blakely, R.J., Sliter, R., and Geist, E.L., 2005, Seismotectonics of the rupture zone of the $1964 \mathrm{MW}=9.2$ great Alaska earthquake [abs.]: Geological Society of America Abstracts with Programs, v. 37, no. 4, p. 44.

Fisher, M.A., Ruppert, N.A., Eberhart-Phillips, D., Brocher, T.M.,Wells, R.E., Blakely, R.J., and Sliter, R.W., 2005, Tectonics and seismicity of the Alaska continental margin near the collision zone of the Yakutat terrane and the epicenter of the 1964 great Alaskan earthquake [abs.]: Geological Society of America Abstracts with Programs, v. 37, no. 7, p. 79.

Fleck, R.J., and Wooden, J.L., 2005, The western Idaho suture zone: Mesozoic crustal boundary [abs.]: Geochimica et Cosmochimica Acta, v. 69, no. 10, supplement, p. A246.

Gautier, D.L., 2005, Kimmeridgian shales total petroleum system of the North Sea Graben Province: U.S. Geological Survey Bulletin 2204-C, 29 p., http://pubs.usgs.gov/bul/2204/c/. Gautier, D.L., Klett, T.R., and Pierce, B.S., 2005, Global significance of reserve growth: U.S. Geological Survey Open-file Report 2005-1355, 25 p., http://pubs.usgs.gov/of/2005/1355/.

Glen, J.M.G., Lerch, D.W., Klemperer, S.L., and Ponce, D.A., 2005, Seismic refraction and potential field modeling from the northwestern Basin and Range transition zone, Nevada and California [abs.]: Eos, Transactions, American Geophysical Union, v. 86, no. 52 (supplement), p. F1841. 
Glen, J.M.G., and Ponce, D.A., 2005, Does hotspot melting pace Great Basin extension? [abs.]: Geological Society of America Abstracts with Programs, Vol. 37, No. 7, p. 200.

Golob, E.M., Baron, D., and Sarna-Wojcicki, A., 2005, Trace-element analysis of four Neogene volcanic ashes: implications for the stratigraphy of petroleum-bearing formations in the San Joaquin Valley, CA [abs.]: Geological Society of America Abstracts with Programs, v. 37, no. 7, p. 181.

Graham, S.E., and Wentworth, C.M., 2005, Derivation of a Pleistocene topographic surface map and a Holocene thickness map for Santa Clara Valley, California [abs.]: Geological Society of America Abstracts with Programs, v. 37, no. 4, p. 91.

Graybeal, F.T., Fleck, R.J., and Vikre, P.G., 2005, Multiple Laramide igneous and hydrothermal events in the Patagonia Mountains, Arizona [abs.]: Geological Society of America Abstracts with Programs, v. 37, no. 7, p. 164

Graymer, R.W., 2005, Jurassic-Cretaceous assembly of central California, in Stevens, C. and Cooper, J., eds., Mesozoic tectonic assembly of California: Pacific Section SEPM (Society for Sedimentary Geology), Book 96, p. 21-64.

Graymer, R.W., Brabb, E.E., Wagner, D.L., Wentworth, C.M., Black, M.C., Jr., Knudsen, K., Wither, R., Clark, J., Jones, D.L., and McLaughlin, R.J., 2005, Complete set of new digital regional geologic map and map databases for San Francisco Bay region, California [abs.]: Geological Society of America Abstracts with Programs, v. 37, no. 4, p. 74.

Graymer, R.W., McLaughlin, R.J., Stanley, R.G., Ponce, D.A., Jachens, R.C., Simpson, R.W., and Wentworth, C.M., 2005, Santa Clara Valley-bounding faults characterized by structural superposition [abs.]: Geological Society of America Abstracts with Programs, v. 37, no. 4, p. 58.

Graymer, R.W., Ponce, D.A., Jachens, R.C., Simpson, R.W., Phelps, G.A., and Wentworth, C.M., 2005, Three-dimensional geologic map of the Hayward fault, northern California: Correlation of rock units with variations in seismicity, creep rate, and fault dip: Geology, v. 33, no. 6, p. 521524.

Hagstrum, J.T., 2005, Antipodal hotspots and bipolar catastrophes: were oceanic large-body impacts the cause?: Earth and Planetary Science Letters, v. 236, no 1-2, p. 13-27.

Hagstrum, J.T., DuBois, R.L., and Blinman, E., 2005, A comparison of paleomagnetic and archaeomagnetic secular variation records for western North America [abs.]: Eos, Transactions, American Geophysical Union, v. 86, no. 52 (supplement), p. F654.

Haugerud, R., 2005, Preliminary geologic map of Bainbridge Island, Washington: U.S. Geological Survey Open-File Report 2005-1387, scale 1:24,000, http://pubs.usgs.gov/of/2005/1387/.

Haugerud, R.A., 2005, Latest Pleistocene landforms near Ferndale, Whatcom County, WA imaged by high-resolution LIDAR survey [abs.]: Geological Society of America Abstracts with Programs, v. 37, no. 7, p. 430.

Haugerud, R.A., Sherrod, B.L., Wells, R.E., and Hyatt, T., 2005, Holocene displacement on the Boulder Creek fault near Bellingham, WA and implications for kinematics of deformation of the Cascadia forearc [abs.]: Geological Society of America Abstracts with Programs, v. 37, no. 7, p. 476.

Hillhouse, J. W., and Jachens, R. C., 2005, Highly magnetic upper Miocene sandstones of the San Francisco Bay Area, California: Geochemistry Geophysics Geosystems, v. 6, no. 5, 15 p., Q05005, doi: 10.1029/2004GC000876.

Hillhouse, J.W., Sarna-Wojcicki, A., Reheis, M., and Forester, R., 2005, Age and paleoenvironments (paleomagnetism, tephra, and ostracodes) of the Pliocene and Pleistocene Tecopa Beds, southeastern California, in Reheis, M.C., ed., Geologic and biotic perspectives on Cenozoic drainage history of the southwestern Great Basin and Lower Colorado River region 
[abs.]; Conference abstracts: U.S. Geological Survey Open-file Report 2005-1404, p. 9 , http://pubs.usgs.gov/of/2005/1404/.

Hook, S.J., Dmochoski, J.E., Howard, K.A., Rowan, L.C., Karlstrom, K.E., and Stock, J.M., 2005, Mapping variations in weight percent silica measured from multispectral thermal infrared imagery-Examples from the Hiller Mountains, Nevada, USA and Tres Virgenes-La Reforma, Baja California Sur, Mexico: Remote Sensing of Environment, v. 95, no. 3, p. 273-289. Hopson, R.F., Hillhouse, J.W., and Howard, K.A., 2005, Comparison of dike azimuths in the Independence dike swarm, California, to paleomagnetic data: Implications for late Cenozoic vertical axis rotations [abs.]: Geological Society of America Abstracts with programs, v. 37, no. 4, p. 102.

House, P.K., Peachtree, P.A., Howard, K.A., Bell, J.W., Perkins, M.E., and Brock, A.L., 2005, Birth of the lower Colorado River-Stratigraphic and geomorphic evidence for its inception near the conjunction of Nevada, Arizona, and California, in Pederson, J., and Kehler, C.M., eds., Interior Western United States: Geological Society of America Field Guide 6, p. 357-387, doi: 10.1130/2005.fld006(17).

Howard, K.A., 2005, The upper crust laid on its side-tectonics of steeply tilted crustal slabs or extension in the Basin and Range [abs.]: Geological Society of America Abstracts with Programs, v. 37, no. 7, p. 419.

Howard, K.A. and Lundstrom, S.C., 2005, The changing paths of the lower Colorado River [abs.], in Reheis, M.C., ed., Geologic and biotic perspectives on Cenozoic drainage history of the southwestern Great Basin and lower Colorado River region; Conference abstracts: U.S. Geological Survey Open-file Report 2005-1404, p. 12-13, http://pubs.usgs.gov/of/2005/1404/.

Howard, K.A. and Nutt, C.J., 2005, Extension-related folds in Eocene rocks, northeastern Nevada [abs.]: Window to the World, Program with Abstracts, Geological Society of Nevada Symposium 2005, Reno/Sparks, NV, May 2005, p. 55-56.

Hudson, D.M., John, D.A., and Fleck, R.J., 2005, Geologic setting, geochemistry, and geochronology of epithermal gold-silver deposits in the Seven Troughs district, northwest Nevada [abs.]: Geological Society of America Abstracts with Programs, v. 37, no. 7, p. 380.

Hudson, M.R., Grauch, V.J.S., Minor, S.A., Thompson, R.A., Sawyer, D.A., Sarna-Wojcicki, A., Caine, J.S., Rodriguez, B.D., Pantea, M.P., and Koning, D.J., 2005, Integrated geologic framework studies in the Espanola Basin, Rio Grande rift, north-central New Mexico [abs.]: Geological Society of America Abstracts with Programs, v. 37, no. 7, p. 147.

Jachens, R.C., Wentworth, C.M., Graymer, R.W., Stanley, R.G., McLaughlin, R.J., Simpson, R.W., Williams, R.A., Anderson, D.W., Ponce, D.A., and Langenheim, V.E, 2005, Late Cenozoic stratigraphic and tectonic history of the Santa Clara Valley, California [abs.]: Geological Society of America Abstracts with Programs, v. 37, no. 4, p. 59.

Jachens, R.C., Wentworth, C.M., Simpson, R.W., Graymer, R.W., Graham, S., Williams, R.A., McLaughlin, R.J., and Langenheim, V.E., 2005, Three-dimensional geologic map of the Santa Clara Valley and adjacent uplands, California [abs.]: Geological Society of America Abstracts with Programs, v. 37, no. 4, p. 89.

Janecke, S.U., Kirby, S., Langenheim, V, Steely, A.N., Dorsey, R., Housen, B., and Lutz, A., 2005, High geologic slip rates on the San Jacinto fault zone in the SW Salton Trough, and possible near-surface slip deficit in sedimentary basins [abs.]: Geological Society of America Abstracts with Programs, v. 37, no. 7, p. 275.

Jarboe, N., Coe, R.S., Glen, J.M.G., and Renne, P.R., 2005, Correlating the Steens $\left(\mathrm{R}_{0}-\mathrm{N}_{0}\right)$ Magnetic Polarity Reversal across the Oregon Plateau [abs.]: Geological Society of America Abstracts with Programs, v. 37, no. 7, p. 207. 
Jarboe, N., Coe, R.S., Glen, J.M.G., and Renne, P.R., 2005, Compilation of a composite geomagnetic polarity reversal path recorded in basalts erupted during initial Yellowstone Hotspot volcanism [abs.]: Eos, Transactions, American Geophyscial Union, v. 86, no. 52 (supplement), p. F648.

Jarboe, N.A., Coe, R.S., Glen, J.M.G., and Renne, P.R., 2005, Correlating the Steens $\left(\mathrm{R}_{0}-\mathrm{N}_{0}\right)$ magnetic polarity reversal across the Oregon plateau [abs.]: Geological Society of America Abstracts with Programs, v. 37, no. 7, p. 207.

Jayko, A.S., 2005, Late Quaternary denudation, Death and Panamint Valleys, eastern California:

Earth Science Reviews, v. 73, no. 1-4, p. 271-289.

Jayko, A.S., 2005, Characteristics of the Sierra Nevada Frontal fault zone and adjacent tectonogeomorphic domains associated with propagation of the PAC-NA plate boundary, western Great Basin [abs.]: Geological Society of America Abstracts with Programs, v. 37, no. 7, p. 59.

Jayko, A.S., Forester, R.M., Kaufmann, D., Philips, F., Mahan, S.A., and McGeehin, J., 2005, Late Pleistocene lakes, Panamint Valley, California [abs.], in Reheis, M.C., ed., Geologic and biotic perspectives on late Cenozoic drainage history of the southwestern Great Basin and lower Colorado River region: Conference abstracts: U.S. Geological Survey Open-File Report 2005-1404, p. 3, http://pubs.usgs.gov/of/2005/1404/.

Jayko, A. S., Menges C. M., and Thompson R. A., 2005, Digital method for regional mapping of surficial basin deposits in arid regions, example from central Death Valley, Inyo County, California: U.S. Geological Survey Open-file Report Open-File Report 2005-1445, 47 p., http://pubs.usgs.gov/of/2005/1445/.

Keller, M.A., 2005, Variation in petroleum source potential of the Kingak Shale, central North Slope Alaska [abstract]: 2005 Annual Convention Abstracts Volume, American Association of Petroleum Geologists (Calgary, Alberta, Canada; June 19-22, 2005), p. A71-A72.

Keller, M.A., and Bird, K.J., 2005, Resolution of conflicting data from the Beaufort Sea Aurora \#1 well clarifies the petroleum source rock potential of the Lower Cretaceous succession, Alaksa [abs.]: Geological Society of America Abstracts with Programs, v. 37, no. 4, p. 93.

Knott, J.R., Sarna-Wojcicki, A.M., Montanez, I.P., and Neff, H., 2005, Solution and time of flight laser ablation ICP-MS measurement of minor and trace elements: an example from Death Valley, California [abs.]: Geological Society of America Abstracts with Programs, v. 37, no. 7, p. 180.

Kulander, C.S., Grow, J.A., Potter, C.J., Saltus, R.W., and Killgore, M.L., 2005, Interpreted regional seismic reflection lines, National Petroleum Reserve in Alaska: U.S. Geological Survey Open-File Report 2005-1402, 25 p., http://pubs.usgs.gov/of/2005/1402/.

Lamb, M.A., Hickson, T., Martin, K.L., and Beard, L.S., 2005, Constraints on the complex Miocene deformational history of the Lake Mead area using detailed basin analysis: tectonic implications of new data from the east and west Longwell Ridge area, Bitter Spring quad, NV [abs.]: Geological Society of America Abstracts with Programs, v. 37, no. 7, p. 127.

Lampe, C., Tscherny, R., Peters, K.E., Bird, K.J., and Magoon, L.B., 2005, What drives volumetrics-Risking petroleum systems on the Alaskan North Slope [abs.]: 2005 Annual Convention Abstracts Volume, American Association of Petroleum Geologists (Calgary, Alberta, Canada; June 19-22, 2005), p. A77.

Langenheim, V.E., DeWitt, E., and Wirt, Laurie, 2005, Preliminary geophysical framework of the upper and middle Verde River watershed, Yavapai County, Arizona: U.S. Geological Survey Open-File Report 2005-1154, 43 p., http://pubs.usgs.gov/of/2005/1154/.

Langenheim, V.E., and Grauch, V.J.S., 2005, Insights into geometry and evolution of extensional basins in the western U.S. from comparison of geologically and geophysically defined locations 
of basin-bounding faults [abs.]: Geological Society of America Abstracts with Programs, v. 37, no. 7 , p. 495.

Langenheim, V.E., Jachens, R.C., Matti, J.C., Hauksson, E., Morton, D.M., and Christensen, A., 2005, Geophysical evidence for wedging in the San Gorgonio Pass structural knot, southern San Andreas fault zone, southern California: Geological Society of America Bulletin, v. 117, no. 11, p. 1554-1572.

Langenheim, V.E., McLaughlin, R.J., Jachens, R.C., Wentworth, C.M., Stanley, R.G., Catchings, R.D., and Mankinen, E.A., 2005, Structure of the Monte Vista fault zone, southwest Santa Clara Valley, California, using geologic, potential-field, and seismic data [abs.]: Geological Society of America Abstracts with Programs, v. 37, no. 4, p. 89.

Langenheim, V.E., Wagner, D.L., Farrar, C.D., and Sweetkind, D.S., 2005, Structure of Sonoma Valley, California revealed by geologic and geophysical mapping: A fault-bend basin within the Rodgers Creek and Bennett Valley fault zones? [abs.]: Geological Society of America Abstracts with Programs, v. 37, no. 4, p. 84.

Leeman, W.P., Lewis, J.F., Evarts, R.C., Conrey, R.M., and Streck, M.J., 2005, Petrologic constraints on the thermal structure of the Cascades arc: Journal of Volcanology and Geothermal Research, v. 140, no. 1-3, p. 67-105.

Lillis, P.G., and Stanley, R.G., 2005, Evaluation of Petroleum source rocks from Yukon Flats, eastcentral Alaska [abs.]: Geological Society of America Abstracts with Programs, v. 37, no. 4, p. 94.

Lindsley-Griffin, N., Farmer, J.D., Griffin, J.R., and Mankinen, E.A., 2005, Reinterpreting the SWEAT hypothesis form the perspective of Ediacaran cyclomedusoids: the BASK connection (Baltica-Alaska-Siberia-Klamath) [abs.]: Geological Society of America Abstracts with Programs, v. 37, no. 4, p. 57.

Machette, M.N., Sarna-Wojcicki, A.M., Liddicoat, J.C., Fleck, R.J., Knott, J.R., and David, B.T., 2005, Tephrochronology, ${ }^{40} \mathrm{Ar} /{ }^{39} / \mathrm{Ar}$ dating, and magnetostratigraphy of the upper part of the Furnace Creek Formation, Death Valley, California [abs.]: Geological Society of America Abstracts with Programs, v. 37, no. 7, p. 180.

Macquaker, J.H.S., and Keller, M.A., 2005, Mudstone sedimentation at high latitudes: Ice as a transport medium for mud and supplier of nutrients: Journal of Sedimentary Research, v. 75, no. 4, p. 696-709.

Macquaker, J.H.S., Polya, D.A., Taylor, K.G., and Keller, M.A., 2005, Another tale of two "shales": how the original composition of mud determined very different petroleum source rock quality [abs.]: 2005 AAPG Annual Convention, June 19-22, 2005, Calgary, Alberta, Canada, Vol.14, p. A84, http://www.searchanddiscovery.com/documents/abstracts/2005annual_calgary/index.htm.

Magoon, L.B., Hudson, T.L., and Peters, K.E., 2005, Egret-Hibernia(!), a significant petroleum system, northern Grand Banks area, offshore eastern Canada: American Association of Petroleum Geologists Bulletin, v. 89, no. 9, p. 1203-1237.

Maher, K., DePaolo, D.J., Christensen, J.N., 2005, A coupled Sr/U isotopic method for quantifying rates of infiltration and silicate dissolution [abs.]: Geological Society of America Abstracts with Programs, v. 37, no. 7, p. 319.

Maher, Kate, Steefel, C.I., and DePaolo, D.J., 2005, Rates of silicate dissolution in deep-sea sediments [abs.]: Geochimica et Cosmochimica Acta, v. 69, no. 10, supplement, p. A776.

Malmon, D.V., Lundstrom, S.C., and Howard, K.A., 2005, A preliminary hypothesis about the origin of late Pleistocene deposits along the lower Colorado River [abs.], in Reheis, M.C., ed., Geologic and biotic perspectives on Cenozoic drainage history of the southwestern Great Basin 
and lower Colorado River region; Conference abstracts: U.S. Geological Survey Open-file Report 2005-1404, p. 19, http://pubs.usgs.gov/of/2005/1404/.

Malmon, D.V., Lundstrom, S.C., and Howard, K.A., 2005, Stratigraphic evidence for climate driven inbalances in the fine-sediment budget of the Colorado River during the Pleistocene [abs.]: Geological Society of America Abstracts with Programs, v. 37, no. 7, p. 296.

Malmon, D.V., Reneau, S.L., Dunne, Thomas, Katzman, Danny, and Drakos, P.G., 2005, Influence of sediment storage on downstream delivery of contaminated sediment: Water Resources Research, v. 41, W05008, doi:10.1029/2004WR003288, 20.

Mankinen, E.A., Sweetkind, D.S., McKee, E.H., and Morin, R.L., 2005, Gravity and ground magnetic data from selected traverses in the Amargosa Desert and vicinity, Nevada and California: U.S. Geological Survey Open-File Report 2005-1444, 43 p., http://pubs.usgs.gov/of/2005/1444/.

Mankinen, E.A., and Wentworth, C.M., 2005, The paleomagnetic record as means of correlating sedimentary sequences encountered in research wells of the Santa Clara Valley, California [abs.]: Geological Society of America Abstracts with Programs, v. 37, no. 4, p. 91.

Martin, K.L., Umhoefer, P., Beard, L.S., Lamb, M.A., Hickson, T., and Blythe, N.O., 2005, Constraints on the complex Miocene deformational history of the Lake Mead area using detailed basin analysis: tectonic implications of new data from the east and west Longwell Ridge area, Bitter Spring quad, NV [abs.]: Geological Society of America Abstracts with Programs, v. 37, no. 7, p. 229.

McDougall, Kristin, 2005, Late Neogene marine incursions and the ancestral Gulf of California [abs.], in Reheis, M.C., ed., Geologic and biotic perspectives on Cenozoic drainage history of the southwestern Great Basin and Lower Colorado River region; Conference abstracts: U.S. Geological Survey Open-file Report 2005-1404, p. 14-15, http://pubs.usgs.gov/of/2005/1404/. McLaughlin, R.J., Sarna-Wojcicki, A.M., Fleck, R.J., Jachens, R.C., Roberts, C.W., Langenheim, V.E., Graymer, R.W., McPhee, D.K., McCabe, C.Z., Valin, Z.C., and Wagner, D.L., 2005, Late Cenozoic volcanism and basin formation within a tectonic setting transitional from subduction to dextral strike-slip, northern San Francisco region, California [abs.]: Geological Society of America Abstracts with Programs, v. 37, no. 4, p. 83.

McLaughlin, R.J., Sarna-Wojcicki, A.M., Fleck, R.J., Wagner, D.L., Clahen, K.B., Langeheim, V.E., and Jachens, R.C., 2005, Constraints on evolution and long-term slip rates for eastern faults of the San Andreas transform boundary from tephrochronology, new ${ }^{39} \mathrm{Ar} /{ }^{40} \mathrm{Ar}$ ages, geologic map relations, gravity and magnetic data [abs.]: Geological Society of America Abstracts with Programs, v. 37, no. 7, p. 181 .

McLaughlin, R.J., Wagner, D.L., Sweetkind, D.S., Sarna-Wojcicki, A.M., Rytuba, J.J., Langenheim, V.E., Fleck, R.J., Jachens, R.C., and Deino, A., 2005, Late Neogene transition from transform to subduction margin east of the San Andreas fault in the wine country of the northern San Francisco Bay Area, California: Pacific Section SEPM (Society for Sedimentary Geology), Book 98, 112 p.

McPhee, D.K., Langenheim, V.E., Jachens, R.C., McLaughlin, R.J., and Roberts, C.W., 2005, Basin structure beneath the Santa Rosa Plain, northern California, and its possible influence on damage patterns from the 1906 and 1969 earthquakes [abs.]: Geological Society of America Abstracts with Programs, v. 37, no. 4, p. 84.

McPhee, D.K., Pellerin, L., Chuckel, B., and Dixon, G.L., 2005, Resistivity imaging of Spring Valley, Nevada using the audiomagnetotelluric method [abs.]: Eos, Transactions, American Geophyscial Union, v. 86, no. 18 (supplement), p. JA188. 
McPhee, D.K., Pellerin, L., Chuchel, B. and Dixon, G.L., 2005, Imaging structure using AMT for hydrological modeling in the western USA [abs.]: Annual Meeting of the European Association of Geoscientists and Engineers, Near Surface Geophysics Division (Palermo, Italy), abstract B053.

Mehringer, P.J., Sarna-Wojcicki, A.M., Wollwage, L.K., and Sheets, Payson, 2005, Age and extent of the Ilopango TBJ tephra inferred from a Holocene chronostratigraphic reference section, Lago de Yojoa, Honduras: Quaternary Research, v. 63, no. 2, p. 199-205.

Menges, C.M., and Anderson, D.E., 2005, Late Cenozoic drainage history of the Amargosa River, southwestern Nevada and eastern California [abs.], in Reheis, M.C., ed., Geologic and biotic perspectives on Cenozoic drainage history of the southwestern Great Basin and Lower Colorado River region; Conference abstracts: U.S. Geological Survey Open-file Report 2005-1404, p. 8, http://pubs.usgs.gov/of/2005/1404/.

Menges, C.M., Pavlis, T.C., McMackin, M.R., Serpa, L., and Bennett, R.A., 2005, Geomorphic and structural evidence for significant neotectonic contractional strain within southern Death Valley and bordering areas, eastern California [abs.]: Geological Society of America Abstracts with Programs, v. 37, no. 7, p. 69.

Messina, P., Stoffer, P., and Smith. W.C., 2005, Macropolygon morphology, development, and classification on north Panamint and Eureka playas, Death Valley National Park CA: EarthScience Reviews, v. 73, no. 1-4, p. 309-322.

Miller, D.M., 2005, Summary of the evolution of the Mojave River [abs.], in Reheis, M.C., ed., Geologic and biotic perspectives on late Cenozoic drainage history of the southwestern Great Basin and lower Colorado River region: Conference abstracts: U.S. Geological Survey OpenFile Report 2005-1404, p. 10-11, http://pubs.usgs.gov/of/2005/1404/.

Miller, D.M., Dudash, S.L., Amaroso, L., Phelps, G.A., Schmidt, K.M., Lidke, D., Redwine, J.L., Bedford, D.R., and Menges, C., 2005, New map of Quaternary faults, northern Mojave Desert: Do previously unrecognized Holocene faults partition strain north toward the Basin and Range? [abs.]: 2005 Southern California Earthquake Council meeting (Palm Springs, CA.; September 11-14, 2005), Proceedings and Abstracts, v. 15, p. 158.

Miller, D.M., Menges, C., Amoroso, L., Schmidt, K.M., Phelps, G.A., Lidke, D., and Dudash, S.L., 2005, New Quaternary geology map of faults, northern Mojave Desert, California [abs.]:

Geological Society of America Abstracts with Programs, v. 37, no. 4, p. 98.

Miller, D.M., Oviatt, C.G., Dudash, S.L., and McGeehin, J.P., 2005, Late Holocene highstands of Great Salt Lake at Locomotive Springs, Utah [abs.]: Geological Society of America Abstracts with Programs, v. 37, no. 7, p. 335.

Morin, R.L., Stanley, R.G., Kumar, N., and Taylor, D.J., 2005, Geophysical expression of the Yukon Flats Basin, east-central Alaska [abs.]: Geological Society of America Abstracts with Programs, v. 37, no. 4, p. 94.

Morton, D.M., and Alvarez, R.M., 2005, Monsoon-generated debris flows, Forest Falls, California [abs.]: Geological Society of America Abstracts with Programs, v. 37, no. 7, p. 35.

Morton, D.M., and Kennedy, M.P., 2005, Preliminary geologic map of the Sage 7.5' quadrangle, Riverside County, California: U.S. Geological Survey Open-File Report 2005-1285, scale 1:24,000, http://pubs.usgs.gov/of/2005/1285/.

Morton, D.M., and Matti, J.C., 2005, Preliminary geologic map of the Hemet 7.5' quadrangle, Riverside County, California: U.S. Geological Survey Open-File Report 2004-1455, scale 1:24,000, http://pubs.usgs.gov/of/2004/1455/. 
Nelson, P.H., and Bird, K.J., 2005, Porosity-depth trends and regional uplift calculated from sonic logs, National Petroleum Reserve in Alaska: U.S. Geological Survey Scientific Investigations Report 2005-5051, 28 p., http://pubs.usgs.gov/sir/2005/5051/.

Oaks, R.Q., Jr., Janecke, S.U., Langenheim, V.E., and Kruger, J.M., 2005, Insights into geometry and evolution of extensional basins along the Wasatch fault and East and West Cache fault zones, Utah and Idaho, USA [abs.]: Geological Society of America Abstracts with Programs, v. 37, no. 7, p. 497.

Oviatt, C.G., Miller, D.M., McGeehin, J.P., Zachary, Cecile, and Mahan, Shannon, 2005, The younger Dryas phase of Great Salt Lake, Utah, USA: Palaeogeography, Palaeoclimatology, Palaeoecology, v. 219, no. 3-4, p. 263-284.

Page, W.R., Lundstrom, S.C., Harris, A.G., Langenheim, V.E., Workman, J.B., Manhan, S.A., Paces, J.B., Dixon, G.L., Rowley, P.D., Burchfiel, B.C., Bell, J.W., and Smith, E.I., 2005, Geologic and geophysical maps of the Las Vegas 30' x 60' Quadrangle, Clark and Nye Counties, Nevada, and Inyo County, California: U.S. Geological Survey Scientific Investigations Map 2814, 58 p., scale 1:100,000, http://pubs.usgs.gov/sim/2005/2814/.

Pease, V., Hillhouse, J. W., Wells, R. E., 2005, Paleomagnetic quantification of upper-plate deformation during Miocene detachment faulting in the Mohave Mountains, Arizona: Geochemistry Geophysics Geosystems, v. 6, no. 9, 20 p., Q09004: doi: 10.1029/2005GC000972,07.

Peters, K.E., and Hostettler, F.D., 2005. Organic materials in geology, in Nibbering, N.M.M., ed., Encyclopedia of Mass Spectrometry, v. 4L: Elsevier (Oxford, England), p. 886-898.

Peters, K.E., Lampe, C., Bird, K.J., and Magoon, L.B., 2005, 4-D modeling of the ShubikIvishak(!) Petroleum System, North Slope, Alaska [abs.]: Geological Society of America Abstracts with Programs, v. 37, no. 4, p. 93.

Peters, K.E., Lampe, Bird, K.J., and Magoon, L.B., 2005, A 4-D petroleum system model for the North Slope, Alaska [abs.]: American Association of Petroleum Geologists Annual Meeting, Calgary, Alberta, June 19-22, 2005, p A109,

http://www.searchanddiscovery.com/documents/abstracts/2005annual_calgary/abstracts/petersO 2.htm.

Peters, K.E., Ramos, S., Zumberge, J.E., and Gautier, D.L., 2005, Circum-Arctic petroleum systems identified by a new chemometric approach [abs.]: 22nd International Meeting on Organic Geochemistry (IMOG) (Seville, Spain; September 12-16, 2005), Abstract OP3-3, p. 48.

Peters, K.E., Walters, C.C., and Mankiewicz, P.J., 2005, Evaluation of kinetic uncertainty in numerical models of petroleum generation, IV [abs.]: Latin American Association of Organic Geochemists (ALAGO) Basin Modeling Workshop (Buenos Aires, Argentina; October 16-19, 2005), CD-ROM without page numbers.

Peters, K.E., Walters, C.C., and Moldowan, J.M., 2005, The biomarker guide, 2nd Edition, v. 1, Biomarkers and isotopes in the environment and human history: Cambridge University Press, Cambridge, U.K., p. 1-472.

Peters K.E., Walters, C.C., and Moldowan, J.M., 2005. The biomarker guide 2nd Edition, v. 2, Biomarkers and isotopes in petroleum and earth history: Cambridge University Press, Cambridge, U.K., p. 473-1155.

Peterson, D.H., Solomon, M., Smith, R., Hager, S., Murphy, F., Stewart, I., and Huber, K., 2005, Monitoring conductivity in high elevation streams draining the central Sierra Nevada [abs]: MTNCLIM 2005 Conference (Mountain Climate), Abstracts (Chico Hot Springs, Pray, MT; March 1-4, 2005), p. 24. 
Peterson, D., Smith, R., Hager, S., Hicke, J., Dettinger, M. , and Huber, K., 2005, River chemistry as a monitor of Yosemite Park Mountain hydroclimates: Eos, Transactions, American Geophysical Union, v. 86, no. 31, p. 285, 288.

Phelps, G.A., Justet, L., Moring, B.C., and Roberts, C.W., 2005, A preliminary investigation of the structure of southern Yucca Flat, Massachusetts Mountain, and CP basin, Nevada Test Site, Nevada, based on geophysical modeling: U.S. Geological Survey Open-File Report 2005-1367, 36 p., http://pubs.usgs.gov/of/2005/1367/.

Phelps, G.A., Roberts, C.W., and Moring, B.C., 2005, Preliminary gravity inversion model of basins east of Yucca Flat, Nevada Test Site, Nevada: USGS Open-File Report 2005-1313, 21 p., http://pubs.usgs.gov/of/2005/1313/.

Phelps, G.A., Robinson, S., and Miller, D.M., 2005, Investigating plant patterns on alluvial fan deposits of the Mojave Desert using high resolution imagery [abs.]: Eos, Transactions, American Geophyscial Union, v. 86, no. 52 (supplement), p. F402.

Phelps, G.A., and Schmidt, K.M., 2005, Demonstrating that the 1989 Loma Prieta earthquake damage in southwestern Santa Clara Valley is non-randomly aligned and is positively associated with mapped lineaments [abs.]: Geological Society of America Abstracts with Programs, v. 37, no. 4 , p. 90.

Pike, R.J., 2005, Digital terrain modeling, in Kempf-Leonard, K., ed., Encyclopedia of Social Measurements: San Diego, CA. Academic Press, v. 1 (of 3), p. 669-675.

Pike, R.J., and Sobieszezyk, S., 2005, San Francisco Bay area debris flows localized by winddriven precipitation [abs.]: Geological Society of America Abstracts with Programs, v. 37, no. 4, p. 78.

Plenier, G., and Glen, J.M.G., 2005, Deciphering magma flow directions from complex magnetic fabrics [abs.]: Eos, Transactions, American Geophysical Union, v. 86, no. 52 (supplement), p. F641.

Pluhar, C.J., Coe, R.S., Sampson, D.E., Glen, J.M.G., Monastero, F.C., and Tanner, S.B., 2005, Lava fingerprinting using paleomagnetism and innovative X-ray fluorescence spectroscopy: A case study from the Coso volcanic field, California: Geochemistry, Geophysics, Geosystems, v. 6, no. 4, 17 p., Q04001, doi:10.1029/2004GC000707.

Plenier, G., and Glen, J.G., 2005, Origin of magnetic complex magnetic fabrics: IRM Quarterly, v. 14, no. 4, p. 2-3.

Ponce, D.A., and Glen, J.M.G., 2005, A prominent basement feature in north-central Nevada and its tectonic implications [abs.]: Geological Society of America Abstracts with Programs, v. 37 , no. 7, p. 378.

Ponce, D.A., Graymer, R.W., Jachens, R.C., Williams, R.A., Simpson, R.W., Wentworth, C.M., and Roberts, C.W., 2005, Southern extension of the Hayward Fault and its relationship to the Silver Creek and Calaveras Faults, northern California [abs.]: Geological Society of America Abstracts with Programs, v. 37, no. 4, p. 90.

Powell, C.L., II, 2005, A preliminary review of California fossil Austrotrophon and Forreria (Gastropoda: Muricidae: Ocenebrinae) [abs.]: Abstracts from joint meeting of 38th annual Western Society of Malacologists and 71st annual American Malacological Society (Pacific Grove, Calif., June 26-30, 2005), p. 94.

Powell, C.L., II, Grant, L., and Conkling, S., 2005, Paleoecologic analysis and age of a late Pleistocene assemblage from upper Newport Bay, Newport Beach, Orange County, California: Veliger, v. 47, no. 3, p. 183-192. 
Powell, C.L., II and Stone, P., 2005, Publications of the Western Earth Surface Processes Team 2004: U.S. Geological Survey Open-File Report 2005-1362, 17 p., http://pubs.usgs.gov/of/2005/1362/.

Premo, W.R., Howard, K.A., and Castineiras, P., 2005, New SHRIMP U-Pb ages and Nd isotopic signatures for plutonism in the northern Ruby-East Humboldt Ranges of NE Nevada; implications for the timing of Tertiary core complex formation [abs.]: Geological Society of America Abstracts with Programs, v. 37, no. 7, p. 359.

Redwine, J.L., 2005, Using surficial geomorphology, soil development, and stratigraphy to estimate the timing and means of incision of Afton Canyon, Mojave Desert, CA [abs.]: Geological Society of America Abstracts with Programs, v. 37, no. 7, p. 431.

Rood, D.H., Busby, C.J., Jayko, A.S., and Luyendyk, B., 2005, Neogene to Quaternary kinematics of the central Sierran Frontal fault system in the Sonora Pass region: Preliminary structural, paleomagnetic, and neotectonic results [abs.]: Geological Society of America Abstracts with Programs, v. 37, no. 4, p. 65.

Rowan, E.L., and Stanley, R.G., 2005, Burial and theremal history models to evaluate hydrocarbon source rock maturity in the Yukon Flats basin, central Alaska [abs.]: Geological Society of America Abstracts with Programs, v. 37, no. 4, p. 95.

Saltus, R.W., Phillips, J.D., Stanley, R.G., Till, A.B., and Morin, R.L., 2005, Geophysical characterization of pre-Cenozoic basement for hydrocarbon assessment, Yukon Flats, Alaska [abs.]: Geological Society of America Abstracts with Programs, v. 37, no. 4, p. 94.

Sarna-Wojcicki, A.M., 2005, Advances and future directions in tephrochronology, western U.S. [abs.]: Geological Society of America Abstracts with Programs, v. 37, no. 7, p. 37.

Sarna-Wojcicki, A.M., Fleck, R.J., Wan, E., Deino, A., and Wagner, D., 2005, Chronostratigraphic framework for the Sonoma Volcanics and associated sediments, long-term fault displacement rates, and areal dispersion of tephra from the source area, central Coast Ranges, California [abs.]: Geological Society of America Abstracts with Programs, v. 37, no. 4, p. 83.

Sarna-Wojcicki, A.M., Reheis, M.C., Pringle, M.S., Fleck, R.J., Burbank, D., Meyer, C.E., Slate, J.L., Wan, E., Budahn, J.R., Troxel, B., and Walker, J.P., Tephra layers of Blind Spring Valley and related upper Pliocene and Pleistocene tephra layers, California, Nevada, and Utah: Isotopic ages, correlation, and magnetostratigraphy: U.S. Geological Survey Professional Paper 1701, 69 p., http://pubs.usgs.gov/pp/pp1701/.

Scheirer, D.S., 2005, Gravity studies of Cave, Dry Lake, and Delamar Valleys, east-central Nevada: U.S. Geological Survey Open-File Report 2005-1339, 36 p., http://pubs.usgs.gov/of/2005/1339/.

Scheirer, D., 2005, Evidence for multiphase basin formation in Pahrump Valley, Nevada and California: reinterpretation of seismic and gravity observations [abs.]: Geological Society of America Abstracts with Programs, v. 37, no. 7, p. 496.

Scheirer, D., Hosford Scheirer, A., and Herr, R., 2005, Discrete and continuous gravity studies of the Arbuckle-Simpson Aquifer, south-central Oklahoma [abs.]: Eos, Transactions, American Geophysical Union, v. 86, no. 52 (supplement), p. F17.

Scheirer, D.S., Sweetkind, D., and Miller, J., 2005, Evidence for multiphase basin formation in Pahrump Valley, Nevada and California: Reinterpretation of seismic and gravity observations [abs.]: Geological Society of America Abstracts with Programs, v. 37, no. 7, p. 496.

Schmidt, K.M., and Reid, M.E., 2005, Rock strength controls on landsliding along the Big Sur coast, CA [abs.]: Geological Society of America Abstracts with Programs, v. 37, no. 4, p. 78. 
Schuenemeyer, J.H., 2005, Methology for the 2005 USGS assessment of undiscovered oil and gas resources, central North Slope, Alaska: U.S. Geological Survey Open-File Report 2005-1410, 82 p., http://pubs.usgs.gov/of/2005/1410/.

Sherrod, B.L., Blakely, R.J., Weaver, C., Kelsey, H., Barnett, E., and Wells, R., 2005, Holocene fault scarps and shallow magnetic anomalies along the southern Whidbey Island Fault Zone near Woodinville, Washington: U.S. Geological Survey Open-File Report 2005-1136, 36 p., http://pubs.usgs.gov/of/2005/1136/.

Simpson, R.W., Jachens, R.C., Graymer, R.W., and Wentworth, C.M., 2005, Seismicity and the major strike-slip faults bordering the Santa Clara Valley, California [abs.]: Geological Society of America Abstracts with Programs, v. 37, no. 4, p. 58.

Stanley, R.G., 2005, Oil and gas potential of Yukon Flats, Alaska [abs.]: 2005 Annual Convention Abstracts Volume, American Association of Petroleum Geologists (Calgary, Alberta, Canada; June 19-22, 2005), p. A132,

http://www.searchanddiscovery.com/documents/abstracts/2005annual_calgary/abstracts/stanley. htm.

Stanley, R.G., Till, A.B., Simpson, M.K., Schenk, C.J., Saltus, R.W., Rowan, E.L., Phillips, J.D., Morin, R.L., Lillis, P.G., and Crews, J.M., 2005, Assessment of undiscovered oil and gas resources in Yukon Flats, east-central Alaska [abs.]: Geological Society of America Abstracts with Programs, v. 37, no. 4, p. 95.

Stanley, R.G., Wentworth, C.M., Williams, R.A., Jachens, R.C., Graymer, R.W., Catchings, R.D., McLaughlin, R.J., Lillis, P.G., White, L.D., and Valin, Z.C., 2005, Concealed sedimentary basins beneath the Santa Clara Valley, California [abs.]: Geological Society of America Abstracts with Programs, v. 37, no. 4, p. 57.

Starratt, S.W., Allen, J.R., Powell, C.L., II, Peterson, D.E., Ruck, E., and Sarna-Wojcicki, A., 2005, New paleontological evidence supporting the Neogene transition from marine to non-marine conditions in Marin and Sonoma Counties, California, USA [abs.]: Geological Society of America Abstracts with Programs, v. 37, no. 4, p. 69.

Stevens, C.H., and Stone, P., 2005, Interpretation of the Last Chance thrust, Death Valley region, California, as an Early Permian décollement in a previously undeformed shale basin: EarthScience Reviews, v. 73, no. 1-4, p. 79-101.

Stevens, C.H., and Stone, P., 2005, Structure and regional significance of the Late Permian(?) Sierra Nevada-Death Valley thrust system, east-central California: Earth-Science Reviews, v. 73, no. 1-4, p. 103-113.

Stevens, C.H., Stone, P., and Miller, J.S., 2005, A new reconstruction of the Paleozoic continental margin of southwestern North America: Iimplications for the nature and timing of continental truncation and the possible role of the Mojave-Sonora megashear, in Anderson, T.H., Nourse, J.A., McKee, J.W., and Steiner, M.B., eds., The Mojave-Sonora megashear hypothesis:

Development, assessment, and alternatives: Geological Society of America Special Paper 393, p. 679-618, doi: 10.1130/2005.2393(22).

Stewart, J.H., and Glen, J.M.G., 2005, Neoproterozoic rocks: History of Neoproterozoic continents indications of a precursor Mesoproterozoic supercontinent [abs.]: Geological Society of America Abstracts with Programs, v. 37, no. 7, p. 217.

Stoffer, P.W., 2005, The San Andreas fault in the San Francisco Bay area, California: A geology field trip guidebook to selected stops on public lands: U.S. Geological Survey Open-File Report 05-1127, 133 p., http://pubs.usgs.gov/of/2005/1127/.

Stoffer, P.W., Chamberlain, J.A., Jr., Scal, R., and Messina, P., 2005, Late Quaternary and early Holocene fossils from New York City beaches: implications for stability in coastal environments 
in western Long Island and New Jersey [abs.]: Geological Society of America Abstracts with Programs, v. 37, no. 7, p. 366.

Stoffer, P.W., and Colvard, E., 2005, USGS Educational Resources: http://education.usgs.gov. [website includes: USGS On-line Resources For Science and History-Social Science Education in California: http://education.usgs.gov/california, and California: Geography, Geology, Hazards, and Natural History Information: http://education.usgs.gov/california/resources.html].

Stoffer, P., and Phillips, E., 2005, 3D Geology of National Parks: http://3dparks.wr.usgs.gov/education.htm.

Stone, P., Barth, A.P., and Wooden, J.L., 2005, U-Pb detrital zircon data from metasedimentary rocks at Black Mountain near Victorville, California-Implications for the age of early Mesozoic Fairview Valley Formation [abs.]: Geological Society of America Abstracts with Programs, v. 37, no. 4, p. 86.

Sweetkind, D., Nutt, C.J., John, D.A., Howard, K., Person, M.A., Ponce, D.A., Glen, J.M.G., and Evans, J., 2005, Tectonic reconstructions based on regional cross sections to increase understanding of metallogeny and fluid flow in the northern Great Basin [abs.]: Geological Society of America Abstracts with Programs, v. 37, no. 7, p. 379.

Sweetkind, D., Rytuba, J.J., Langenheim, V.E., and Sarna-Wojcicki, A.M., 2005, Contrasting styles of volcanism along the east side of Napa Valley, CA [abs.]: Geological Society of America Abstracts with Programs, v. 37, no. 4, p. 84.

Sweetkind, D., Wallace, A.R., Nutt, C.J., John, D.A., Howard, K.A., Ponce, D.A., Glen, J.M.G., Moore, T.E., and Hofstra, A.H., 2005, Reconstructing northern Great Basin geologic and mineralizing events using regional cross sections [abs.]: Window to the World, Program with Abstracts, Geological Society of Nevada Symposium 2005, Reno/Sparks, Nevada, May 2005, p. 8.

Tabor, R.W., Frizzell, V.A., Jr., Booth, D.B., Waitt, R.B., Whetten, J.T., and Zartman, R.E., 2001 [2005], Geologic map of the Skykomish River 30- by 60-minute quadrangle, Washington: U.S. Geological Survey Geologic Investigations Series I-1963, 67 p., scale: 1:100,000, http://pubs.usgs.gov/imap/i1963/. [Updated in 2005 to include digital database.]

Tabor, R.W., Waitt, R.B., Frizzell, V.A., Jr., Swanson, D.A., Byerly, G.R., and Bently, G.R., 2005, Geologic map of the Wenatchee 1:100,000 quadrangle, central Washington: a digital database:

U.S. Geological Survey Data Series 137, version 1, http://pubs.usgs.gov/ds/137/.

Tilden, J.E., Blakely, R.J., and Johnson, S.Y., 2005, Active deformation offshore southwestern San Juan Island, Washington: Implications for seismic hazard assessment [abs.]: Geological Society of America Abstracts with Programs, v. 37, no. 4, p. 44.

Tilden, J.E., Ponce, D.A., Glen, J.M.G., and Gans, K.D., 2005, Gravity and magnetic data along a seismic refraction-reflection line in northwest Nevada and northeast California: U.S. Geological Survey Open-File Report 2005-1446, 14 p., http://pubs.usgs.gov/of/2005/1446/.

Tilden, J.E., Ponce, D.A., Glen, J.M.G., John, D.A., and Person, M., 2005, Three-dimensional geologic model of the Beowawe geothermal area, north-central Nevada [abs.]: Geological Society of America Abstracts with Programs, v. 37, no. 7, p. 380.

Till, A.B., Stanley, R.G., O'Sullivan, P.B., Saltus, R.W., and Crews, J., 2005, Tectonic events leading to establishment of Yukon Flats basin, Alaska [abs.]: Geological Society of America Abstracts with Programs, v. 37, no. 4, p. 94.

Troost, K.G., Booth, D.B., Wisher, A.P., and Shimel, S.A., 2005, The geologic map of Seattle-A progress report: U.S. Geological Survey Open-File Report 2005-1252, scale 1:24,000, http://pubs.usgs.gov/of/2005/1252/. 
Valin, Z.C., and McLaughlin, R.J., 2005, Locations and data for water wells of the Santa Rosa Valley, Sonoma County, California: U.S. Geological Survey Open-File Report 2005-1318, 16 p., http://pubs.usgs.gov/of/2005/1318/.

Verma, M.K., Bird, K.J., Nelson, P.H., and Burruss, R.C., 2005, Evaluation of the stranded Kavik gas field, north slope of Alaska [abs.]: Geological Society of America Abstracts with Programs, v. 37 , no. 4 , p. 92.

Vikre, P., Fleck, R., and Rye, R., 2005, Ages and geochemistry of magmatic hydrothermal alunites in the Goldfield District, Esmeralda Co., Nevada: U.S. Geological Survey Open-File Report 2005-1258, 2 p., http://pubs.usgs.gov/of/2005/1258/.

Wagner, D., Fleck, R., McLaughlin, R., and Sarna-Wojcicki, A., 2005, New constraints on the age and distribution of Cenozoic volcanics north of San Pablo Bay, California: Implications for displacement along faults inboard of the San Andreas fault [abs.]: Geological Society of America Abstracts with Programs, v. 37, no. 4, p. 83-84.

Wagner, D.L., Sarna-Wojcicki, A., and McLaughlin, R.J., 2005, Implications of new chemical correlations of tephra for displacement along the Rodgers Creek and Hayward faults, northern San Francisco Bay region, California [abs.]: Geological Society of America Abstracts with Programs, v. 37, no. 7, p. 181.

Webb, R.H., Fenton, C.R., and Howard, Keith, 2005, Age of landslide-dammed lake deposits in central Grand Canyon, Arizona [abs.]: Geological Society of America Abstracts with Programs, v. 37, no. 7, p. 296.

Webb, R.H., Hereford, R., and McCabe, G.J., 2005, Climatic fluctuations, drought, and flow in the Colorado River, in Gloss, S.P., Lovich, J.E., and Mellis, T.E., eds., The state of the Colorado River ecosystem in Grand Canyon: A report of the Grand Canyon Monitoring and Research Center 1991-2004: U.S. Geological Survey Circular 1282, p. 57-67, http://www.gcmrc.gov/products/score/2005/pdf/score_2005.pdf.

Wells, R.E., Blakely, R.J., Dragert, H., Kao, H., MaLausland, W., and Malone, S., 2005, Coseismic slip and deep tremor in subduction zones and their relation to crustal structure revealed by gravity anomalies [abs.]: Geological Society of America Abstracts with Programs, v. 37, no. 4, p. 44.

Wells, R.E., Rymer, M.J., Prentice, C.S., and Wheeler, K.L., 2005, Map showing features and displacements of the Scenic Drive Landslide, La Honda, California, during the period March 31May 7, 2005: U.S. Geological Survey Open-File Report 2005-1191, scale 1:400, http://pubs.usgs.gov/of/2005/1191/.

Wentworth, C.M., and Tinsley, J.C., 2005, Tectonic subsidence and cyclic Quaternary deposition controlled by climate variation, Santa Clara Valley, California [abs.]: Geological Society of America Abstracts with Programs, v. 37, no. 4, p. 5.

Wentworth, C.M., Tinsley, J.C., Anderson, D.W., Graham, S.E., Jachens, R.C., Mankinen, E.A., and Williams, R.A., 2005, Quaternary deposits of the Santa Clara Valley, California [abs.]: Geological Society of America Abstracts with Programs, v. 37, no. 4, p. 58.

Williams, R.A., Stephenson, W.J., Wentworth, C.M., Jachens, R.C., Hanson, R.T., Simpson, R.W., Odum, J.K., and Stanley, R.G., 2005, Constraints on faults and basins within the Santa Clara Valley, California, from seismic-reflection data [abs.]: Geological Society of America Abstracts with Programs, v. 37, no. 4, p. 59.

Wilson, R.C., and Pike, R.J., 2005, Watching for landslide weather in California: Geotimes, v. 50, no. 11, p. 28-31.

Woolace, A.C., Kelsey, H.M., Sarna-Wojcicki, A.M., and Simpson, G., 2005, Late Neogene and Quaternary stratigraphy and structure of Little Lake (Willits) Valley, northern Coast Range, California [abs.]: Geological Society of America Abstracts with Programs, v. 37, no. 4, p. 68. 
Yerkes, R.F., and Campbell, R.H., 2005, Preliminary geologic map of the Los Angeles 30' x 60' quadrangle, southern California: U.S. Geological Survey Open-File Report 2005-1019, scale 1:100,000, http://pubs.usgs.gov/of/2005/1019. 